\title{
Metode Penetapan Fatwa Majelis Ulama Indonesia (Analisis Penggunaan Qawaid Fiqhiyyah sebagai Dalil Mandiri dalam Fatwa)
}

\author{
Moh. Mundzir \\ Institut Agama Islam Nahdlatul Ulama Tuban \\ E-mail: mohamadmundzir71@gmail.com
}

\begin{abstract}
Abstrak: Penggunaan qawa' id fiqhiyyah sebagai dalil untuk menyelesaikan persoalan- persoalan hukum yang muncul di tengah-tengah masyarakat, sebagaimana dilakukan oleh MUI, tidak dilakukan oleh lembaga-lembaga serupa yang ada pada organisasi sosial- keagamaan di Indonesia seperti NU dan Muhammadiyah. Akibatnya apabila persoalan tersebut tidak ditemukan di dalam pendapat para ulama dalam kitab-kitab fikih, keputusan yang diambil oleh MUI berbeda dengan keputusan oleh LBM NU dan Majelis Tarjih Muhammadiyah yang sering memberikan status mauquf (ditangguhkan) terhadap persoalan yang dihadapi. Oleh karena itu, penelitian ini dimaksudkan untuk menjawab pertanyaan: bagaiamana qawa'id fighiyyah digunakan di dalam penetapan fatwafatwa MUI? mengapa MUI menggunakan qawa'id fighiyyah sebagai dalil dalam fatwa-fatwanya?. Sumber data penelitian ini adalah fatwa MUI tahun 1975-2018, sementara pendekatannya adalah content analysis dan yuridis hukum Islam. Penelitian ini menemukan bahwa penggunaan qawa'id fiqhiyah sebagai dalil ('adillah al-ahkam) dalam fatwa-fatwa MUI, diposisikan sama sebagaimana posisi al-Sunnah terhadap al-Qur'an yaitu sebagai ta'kid/mu'akkid, tabyin/mubayyin, dan taqriri/taqnin. Dalam kondisi demikian MUI menggunakan qawa'id fiqhiyyah. (prinsip-prinsip yang ada dalam kaidah-kaidah fikih) sebagai pertimbangan utama (dalil mandiri) untuk menyelesaikan persoalan tersebut.

Kata kunci: Fatwa MUI, qawa'id fiqhiyyah, dalil.
\end{abstract}

\section{Pendahuluan}

Majelis Ulama Indonesia (MUI) merupakan salah satu lembaga kajian hukum Islam yang intens menggunakan qawa'id fiqhiyyah sebagai landasan dalam menyelesaikan problematika hukum (Islam). Sejak 
tahun 1975 sampai 2018 MUI melalui Komisi Fatwa dan Dewan Syariah Nasional (DSN) telah menetapkan lebih dari 380 fatwa. Dari seluruh fatwa tersebut ada 200 fatwa yang mencantumkan qawa' id fighiyyah sebagai dalil, di antara dalil- dalil yang lain (al-Qur"an, al-Sunnah, atau pendapat-pendapat fuqaha). MUI dalam menggunakan qawa'id fighiyyah sebagai landasan dalam menyelesaikan problematika hukum tersebut tidak terbatas pada wilayah akidah dan ibadah, tetapi juga dalam wilayah sosial budaya dan masalah-masalah kontemporer yang muncul akibat perkembangan teknologi yaitu pangan, obat-obatan, dan kosmetika serta keuangan. Dalam bidang keuangan, melalui Dewan Syariah Nasional (DSN), lebih dari 100 fatwa yang dikeluarkan, hampir seluruhnya menyertakan qawa'id fighiyyah sebagai dalil.

Penggunaan qawa'id fighiyyah sebagai dalil untuk menyelesaikan persoalan-persoalan hukum ynag muncul di tengah-tengah masyarakat, sebagaimana dilakukan oleh MUI tersebut, tidak dilakukan oleh lembagalembaga serupa yang ada pada organisasi sosial-keagamaan di Indonesia seperti NU dan Muhammadiyah. NU melalui Lembaga Bahtsul Masail (LBM), dalam menetapkan hukum terhadap persoalan-persoalan yang muncul, baik di tingkat pusat, wilayah, maupun cabang, sangat minim (untuk mengatakan tidak ada) dalam menggunakan qawa' id fighiyyah sebagai dalil. Lembaga Bahtsul Masail (LBM) ini lebih banyak merujuk pada pendapat "jadi" para Imam Mazhab atau pengikutnya (khususnya Syafi'iyyah). Hal ini berarti metode qauliy yaitu mencari pendapat para ulama yang sudah ada dalam kitab-kitab lebih dominan digunakan daripada qawa'id fighiyyah sebagai landasan metodologis (manhajiy) dalam menyelesaikan persoalan-persoalan hukum yang dihadapi. Akibatnyaapabila persoalan tersebut tidak ditemukan dalam pendapat para ulama dalam kitab-kitab fikih, sikap atau keputusan yang diambil terhadap persoalan yang dihadapi adalah mauquf(ditangguhkan). Demikian juga Muhammadiyah. Pembahasan-pembahasan hukum yang dilakukan oleh Majlis Tarjih, sangat minim dalam menggunakan qawa'id fighiyyah sebagai dalil.

\section{Posisi Qawa'id Fiqhiyyah dalam Fatwa MUI}

Metode yang digunakan oleh MUI dalam Menetapkan Fatwa diatur dalam keputusan fatwa MUI Nomor Istimewa/VII/2012 tanggal 1 Juni 2012 tentang Pedoman dan Prosedur Penetapan Fatwa Majelis Ulama 
Indonesia (MUI). ${ }^{1}$ Sebagaimana telah dijelaskan sebelumnya bahwa penetapan fatwa terhadap persoalan-persoalan hukum (agama) secara umum, dilakukan oleh Komisi Fatwa ${ }^{2}$, kecuali dalam persoalan-persoalan perekonomian dan keuangan syariah yaitu dilakukan oleh Dewan Syariah Nasional (DSN). ${ }^{3}$ Persoalan-persoalan yang ditetapkan oleh Komisi Fatwa ada dua kemungkinan, pertama atas pertanyaan atau permintaan dari masyarakat, pemerintah, lembaga/oraganisasi, atau dari MUI sendiri. Kedua berdasarkan temuan masalah yang muncul akibat perkembangan dan perubahan sosial masyarakat, kemajuan ilmu pengetahuan dan teknologi, serta seni budaya. ${ }^{4}$

Dalam membahas atau mengkaji persoalan yang akan difatwakan MUI dapat menghadirkan pakar atau ahli yang berkaitan dengan masalah yang akan difatwakan. ${ }^{5}$ Penetapan fatwa dilakukan harus setelah dilakukan pembahasan secara mendalam dan komprehensif serta memperhatikan pendapat dan pandangan dari para peserta ${ }^{6}$. Beberapa hal penting yang dapat dikemukakan dari penjelasan tersebut adalah: pertama penetapan fatwa yang dilakukan oleh MUI tidak dilakukan atau

\footnotetext{
${ }^{1}$ Pada mulanya MUI belum mempunyai format (prosedur) baku perihal mekanisme penetapan Fatwa. Metodologi penetapan fatwa MUI senantiasa berubah sesuai dengan kondisi dan kebutuhan sosial dan politik pada saat itu. Bahkan di bawah kepemimpinan Ghozali, MUI tidak menetapkan fatwa apapun. Seiring berjalannya waktu, MUI mulai menerapkan format penetapan fatwa dengan menempatkan madzhab Syafii sebagai dominasi dalam penetapan fatwa hukum Islam di Indonesia. Oleh karenanya, penetapan fatwa MUI di Indonesia lebih bercorak pada fikih Syafiliyyah. Lihat dalam Syafiq Hasyim, Council of Indonesian Ulama (Majelis Ulama Indonesia, MUI) and its Role in the Shariatisation (Berlin: Freie Universitat, 2013),hlm. 87-90. Baru pada tanggal 30 Januari 1986 sebuah buku pedoman terperinci dalam mengeluarkan fatwa yang dikeluarkan oleh MUI, yang menerangkan bahwa dasar-dasar untuk mengeluarkan fatwa, menurut urutan tingkat, adalah: Al-Qur"an, Sunnah, Ijmak, dan qiyas. Hal ini masih harus disusuli dengan penelitian pendapat para imam mazhab yang ada dan fuqoha, yang telah melakukan penelaahan mendalam tentang masalah serupa. Lihat dalam Mohammad Atho Mudzhar, Fatwas of The Council of Indonesia Ulama: A Study of Islamic Legal Thought in Indonesia 1975-1988 (Jakarta: INIS, 1993), hlm. 75

2 Keputusan Komisi Fatwa MUI No. Istimewa/VII/2012 tanggal 1 Juni 2012 tentang "Pedoman dan Prosedur Penetapan Fatwa MUI" Bab II pasal 2. Lihat Sekretariat MUI, Himpunan Fatwa MUI Sejak 1975 (Jakarta: Erlangga, 2015),hlm. 9

${ }^{3}$ Pedoman Dasar Dewan Syariah Nasional MUI yang ditetapkan oleh DSN-MUI bagian “Tugas dan Wewenang" DSN. Lihat Sekretariat MUI, Himpunan Fatwa Keuangan Syariah DSN MUI (Jakarta: Erlangga, 2014), hlm. 13-14

${ }^{4}$ Pedoman dan Prosedur Penetapan Fatwa MUI Bab IV pasal 9. Lihat Sekretariat MUI, Himpunan Fatwa MUI, 11

5 Pedoman dan Prosedur Penetapan Fatwa MUI Bab IV pasal 8 (2)

${ }^{6}$ Pedoman dan Prosedur Penetapan Fatwa MUI Bab IV pasal 11 (1)
} 
diserahkan kepada perorangan tetapi kepada beberapa orang yang mempunyai kompetensi terhadap persoalan yang diajukan. Penetapan dengan cara tersebut dalam usul figh disebut dengan metode ijtihad kolektif (jama'iy). Kedua, dalam penetapkan fatwa, Komisi Fatwa tidak boleh bersikap pasif, menunggu persoalan yang diajukan, tetapi harus responsif dan proaktif, bahkan antisipatif yaitu peka terhadap persoalanpersoalan yang menjadi wewenang dan tugasnya untuk diselesaikan.

Selanjutnya, dalam pasal 3 dijelaskan bahwa dasar yang digunakan oleh Komisi Fatwa MUI dalam menetapkan fatwa adalah al-Qur'an, hadis, ijmak, qiyas dan dalil-dalil lain yang mu'tabar. ${ }^{7}$ Pasal ini menunjukkan bahwa MUI masih memegangi dalil yang dipegangi jumhur fuqaha' (muttafaq alaih) sebagai rujukan utama. Menarik juga untuk diperhatikan, selain menggunakan dalil-dalil tersebut, dalam pasal 4 (2) disebutkan bahwa penetapan fatwa harus argumentatif, kontekstual (waqi'iy), aplikatif, dan moderat. Hal ini menunjukkan bahwa dalam menetapkan fatwa, MUI tidak boleh semata-mata hanya berpegangan terhadap nas an sich, tetapi juga harus didasarkan atas nalar atau logika yang kuat. Kekuatan argumentasi nalar atau logika tersebut antara lain ditunjukkan sejauh mana produk fatwa tersebut memperhatikan situasi dan kondisi di mana produk fatwa tersebut akan diterapkan. Prinsip kontekstual (waqi'iy) juga penting, karena dengan prinsip tersebut akan berakibat pada efektif atau tidaknya fatwa, dan sekaligus menghindari kesan ekstrim terhadap sebuah fatwa. Fatwa yang tidak memperhatikan konteks akan mengalami kesulitan dalam pelaksanaannya, dan fatwa yang tidak moderat, akan resisten terhadap kontradiktifitas.

Hal lain yang juga perlu dikemukakan adalah dalam Bab III pasal 5 (1) disebutkan; sebelum fatwa ditetapkan, dilakukan kajian komprehensif terlebih dahulu guna memperoleh deskripsi utuh tentang obyek masalah (tasawwur al-mas'alah), rumusan masalah termasuk dampak sosial keagamaan yang ditimbulkan dan titik kritis dari berbagai aspek hukum (norma syariah) yang berkaitan dengan masalah tersebut. Poin penting dari pasal ini, MUI sebagai organisasi yang salah satu tugasnya adalah memberikan jawaban (fatwa) atas persoalan- persoalan hukum

\footnotetext{
7 Pedoman dan Prosedur Penetapan Fatwa MUI Bab II pasal 3. Dalam pedoman tersebut tidak ada penjelasan tentang yang dimaksud dalil mu'tabar. Untuk dalil ijmak jarang sekali digunakan, sedangkan untuk dalil qiyas, operasionalisasinya MUI menggunakan kaidah-kaidah fikih
} 
(keagamaan) bagi umat (Islam), tidak hanya sekedar menjawab substansi hukum an sich. Faktor lain di luar substansi persoalan hukum yaitu dampak negatif, yang dalam pasal tersebut ada dalam kalimat "dampak sosial keagamaan yang ditimbulkan" perlu dijaga. Untuk menjaga dampak negatif tersebut, dalam konteks ijtihad ada pada metode sadd azzari' ah dan dalam operasionalnya MUI menggunakan kaidah-kaidah fikih. ${ }^{8}$

Prinsip untuk menghindari dampak negatif fatwa ini dikuatkan dalam pasal 6 ayat 4 yaitu "penetapan fatwa harus mempertimbangkan kemaslahatan umum dan maqasid syari'ah". Dalam konteks ijtihad prinsip ini ada dalam metode ijtihad istilahiy atau maslahah mursalah dan dalam operasionalisasinya MUI menggunakan kaidah-kaidah fikih yang berkaitan dengan maslahah. Selanjutnya dalam ayat 2 dijelaskan tentang yang dimaksud kajian komprehensif yang ada pada ayat 1 di atas yaitu dalam mengkaji suatu persoalan hukum, komisi fatwa harus memperhatikan pendapat atau pandangan fuqaha' masa lalu, pendapat para imam mazhab, fatwa-fatwa yang terkait, dan para ahli fikih yang terkait dengan masalah yang difatwakan. Poin penting dari ayat yang ada pada pasal ini adalah dalam menetapkan fatwa terhadap persoalanpersoalan yang muncul, MUI masih mencari rujukan pendapatpendapat fuqaha' yang ada dalam kitab-kitab fikih, dan pendapat (fikih) yang digunakan sebagai rujukan dalam menetapkan fatwa tidak terikat pada satu mazhab, tetapi boleh dengan menggunakan pendapat beberapa mazhab. Metode ini dalam usul al-figh dikenal dengan istilah talfiq (eklektik).

Hal ini dapat dilihat dalam pasal 6 (4) yaitu apabila di antara pendapat-pendapat yang di kalangan para imam mazhab tidak tercapai titik temu maka dalam keputusan fatwa harus disampaikan tentang adanya perbedaan pendapat tersebut disertai argumen masing-masing. Ini artinya tidak menutup kemungkinan dalam suatu keputusan fatwa, ketentuan hukumnya tidak tunggal. Keputusan fatwa tidak tunggal atau dengan metode eklektik (talfiq) ini antara lain dapat dilihat dalam

8 Kaidah-kaidah fikih yang digunakan untuk mengoperasionalkan metode sadd az-zari'ah

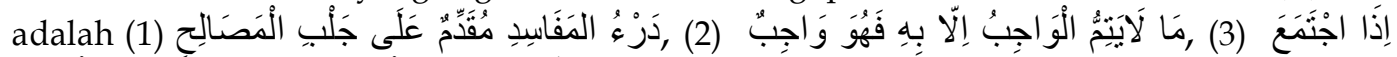

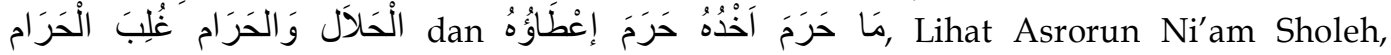
Metodologi Penetapan Fatwa MUI: Penggunaan Prinsip Pencegahan dalam Fatwa, (Jakarta: Erlangga, 2016), hlm. 55-56 
fatwa MUI yang dikeluarkan pada tanggal 12 Nopember 1984 tentang "memakan dan membudidayakan kodok". Dalam keputusan fatwanya MUI membenarkan pendapat mazhab Syafii dan jumhur ulama yang mengharamkan memakan daging kodok, dan juga membenarkan pendapat imam Maliki yang menghalalkan daging kodok.

Kemudian dalam pasal 6 ayat 1 disebutkan, terhadap persoalan yang telah jelas hukum dan dalilnya (ma'lum min ad-din bi ad-darurah) maka penetapan fatwa disampaikan apa adanya sesuai dalil tersebut. Hal ini menunjukkan metode qawliy tetap dipegang teguh oleh MUI. Artinya ketika persoalan yang dipertanyakan tersebut sudah ada nass yang qath'iy, MUI mencukupkannya dengan nass tersebut. Oleh karena itu dalam keputusan fatwanya, MUI tidak mencantumkan penjelasan atau tafsir terhadap al-Qur'an yang dicantumkan sebagai dalil fatwa tersebut. Demikian juga MUI tidak mencantumkan syarah (komentar atau pendapat) tentang hadis yang dicantumkan sebagai dalil fatwa tersebut.

Terkait dengan problem hukum yang tidak ada dalilnya baik dalam nas maupun pendapat di kalangan mazhab, dalam ayat 3 disebutkan penetapan fatwa didasarkan pada ijtihad kolektif (ijtihad jama'iy) dengan menggunakan metode bayaniy dan ta'liliy yaitu qiyasiy, istihsaniy, ilhaqiy, istislahiy, dan saad adz-dzari'ah. Ayat ini menunjukkan bahwa selain pola pikir qauliy, pola pikir metodologis (manhajiy) juga digunakan oleh MUI dalam menetapkan fatwa. Pola pikir metodologis yang ada pada konsep qiyas, istislahiy dan saad adz-dzari'ah tersebut secara operasional-praktis ada dalam konsep qawa'id fighiyyah melalui metode ilhoqiy.

Dalam pasal 6 ayat 2 bagian huruf "a" disebutkan, apabila pendapat yang dijadikan dasar fatwa terdapat perbedaan maka diupayakan pencapaian titik temu, sedapat mungkin keluar dari perbedan pendapat, melalui metode al-jam'u wa at-taufiq. Prinsip menghindari perbedaan pendapat ini dalam konteks qawa'id fighiyyah terdapat dalam kaidah الخُرُوْجُ مِنَ الْخِلَافِ مُسنَتَبَ Kaidah ini memberikan jalan keluar apabila terjadi perbedaan dan sekaligus memberikan peluang kepada mujtahid atau mufti untuk menemukan hukum baru atau menetapkan fatwa dengan tidak merujuk pada berbagai macam pendapat yang berbeda-beda tersebut, apabila pendapat baru tersebut dianggap lebih rasional dan relevan. Kemudian pada bagian " $b$ " disebutkan, apabila tidak tercapai titik temu maka penetapan fatwa didasarkan pada hasil 
tarjih (memilih pendapat yang dianggap lebih kuat) melalui metode muqaranah (perbandingan) dengan menggunakan kaidah-kaidah usul alFiqh muqarran. Dalam penelusuran penulis, kaidah usul al-figh (al-qawa'id al-usuliyah) yang digunakan untuk mencari jalan tengah terhadap adanya khilafiyah di kalangan para ulama mazhab sangat minim digunakan. Penggunaan kaidah fikih (al-qawa'id al-fighiyyah) lebih dominan dari pada kaidah usul al-figh (al-qawa'id al-usuliyyah). Dominasi penggunaan qawa'id fighiyyah menunjukkan bahwa metode ilhaqiy dengan kemaslahatan dan kemadaratan sebagai basis pertimbangan('illah)nya, merupakan metode yang utama digunakan oleh MUI dalam menetapkan fatwanya.

Secara teknis operasional, penggunaan dalil secara umum termasuk di dalamnya penggunaan qawa'id fighiyyah sebagai bangunan legitimasi dalam berfatwa, MUI mengaturnya dalam Pedoman dan Prosedur penetapan Fatwa MUI. Di Bab V tentang Format Fatwa disebutkan, keputusan fatwa dirumuskan dengan bahasa hukum yang mudah dipahami oleh masyarakat luas (pasal 12). Format fatwa harus memuat: Pertama, nomor dan tema fatwa (pasal 13 ayat 1). Kedua, kalimat basmalah (pasal 13 ayat 2). Ketiga, konsideran (pasal 13 ayat 3) yang terdiri atas; a). Menimbang; yang memuat latar belakang dan alasan serta urgensi penetapan fatwa. b). Mengingat; memuat dasar-dasar hukum ('adillah alahkam) yang berbentuk nass syari', terjemah dalam bahasa Indonesia, dan penjelasan terkait pemanfaatan dalil sebagai argumen (wajh ad-dilalah). c). Memperhatikan; memuat pendapat para ulama, peserta rapat, para ahli, dan hal-hal lain yang mendukung penetapan fatwa (walaupun tidak semua fatwa mencantumkannya). Keempat, Diktum (pasal 13 ayat 4) yang memuat; a). Ketentuan Umum; yang berisi tentang definisi dan batasan pengertian masalah yang terkait dengan fatwa, jika dipandang perlu. b). Ketentuan hukum; yang berisi tentang substansi hukum yang difatwakan. c). Rekomendasi dan atau solusi masalah jika dipandang perlu. Dan kelima, lampiran-lampiran terkait masalah yang difatwakan, jika dipandang perlu.

Dalam keputusan fatwa MUI, qawaid fighiyyah dituangkan dalam frasa "mengingat" pada bagian konsideran. Frasa "mengingat" memuat dasar-dasar hukum ('adillah al-ahkam) yang digunakan sebagai dalil untuk menentukan hukum atas suatu permasalahan tertentu. Qawaid fiqhiyyah berada dalam satu hirarki dengan nas yaitu dalam frasa "mengingat" dan peletakannya setelah al-Qur"an dan hadis (as-Sunnah), dan berada di atas 
hirarki pendapat para ulama, peserta rapat, para ahli, dan hal-hal lain yang mendukung penetapan fatwa, yang ada dalam frasa "memperhatikan". Dengan diletakkannya qawa'id fighiyyah dalam satu hirarki dengan al-Qur"an dan hadis dalam frasa "mengingat", menunjukkan bahwa qawa'id fighiyyah menempati posisi penting sebagai dalil fatwa.

\section{Qawā'id Fiqhiyyah sebagai Dalil Mandiri dalam Fatwa-Fatwa MUI}

Sebagaimana diketahui dalam hirarki dalil hukum ('adillah al-ahkam) ada dua yaitu naqliy dan aqliy. Dalil naqliy adalah wahyu atau nass yaitu berupa al-Qur'an dan as-Sunnah, sedang dalil aqliy berupa akal, ratio (logika). Dikatakan hirarki karena dalam operasionalisasinya, baik untuk menetapkan hukum atau fatwa dan menyelesaikan problematika hukum, dalil naqliy harus didahulukan. Apabila tidak dapat merujuk kepada dalil naqliy maka baru beralih kepada dalil aqliy. Walaupun keberadaan asSunnah sama- sama sebagai dalil naqliy dengan al-Qur"an, tetapi secara hirarkis berada di bawah al-Qur"an. Dalam konteks hirarki as-Sunnah di bawah al-Qurean ini, para ulama usul fikih membahas fungsi atau posisi as-Sunnah tersebut terhadap hirarki dalil di atasnya yaitu al-Qur"an. Fungsi tersebut pertama sebagai penguat, penegas, atau pengukuh ( $\left.t a^{\prime} k i d, \quad m u^{\prime} a k k i d\right)$ terhadap ketentuan-ketentuan al-Qur"an. Artinya pada posisi ini ketentuan-ketentuan hukum yang di al-Qur"an dikuatkan oleh as-Sunnah, karena ketentuan yang ada dalam as-Sunnah tersebut sama dengan yang ada dalam al-Qur"an. Kedua sebagai penjelas (tabyin, mubayyin) terhadap ketentuan-ketentuan yang ada di dalam al-Qur"an. Pada fungsi ini as-Sunnah diposisikan untuk menjelaskan secara teknis terhadap ketentuan-ketentuan al-Qur"an yang masih umum (tabyi@n almujmal) atau mengecualikan ketentuan-ketentuan hukum yang memiliki cakupan umum (takhsil al-'äm). Ketiga, menetapkan, membentuk, atau menciptakan hukum baru (taqrir, taqnin) terhadap persoalan-persoalan yang tidak ada di dalam al-Qur"an dan as-Sunnah. ${ }^{9}$ Pada fungsi ini asSunnah diposisikan sebagai dalil ketika suatu problem hukum tidak ada ketentuannya dalam al-Qur'an.

Posisi as-Sunnah terhadap al-Qur"an yang ketiga adalah untuk

\footnotetext{
${ }^{9}$ Abdul Wahhab Khallaf, Ilmu Usul Figh (Kairo: Maktabah Islamiyyah, 1990), hlm. 25. Lihat juga Amir Syarifuddin, Ushul Figh I (Jakarta: Kencana, 2008), 93-95. Forum Kajian Ilmiah PP Lirboyo, Kilas Balik Teoritis Figh Islam (Kediri: Pokja Forum Karya Ilmiah, 2005),hlm. 47-49.
} 
menetapkan atau membentuk ketentuan hukum (taqrir atau taqnin) tentang hukum-hukum yang tidak ada dalam al-Qur"an.10 Posisi qawā'id fighiyyah sebagai dalil mandiri atau dalil otonom dianalogikan dengan posisi as-Sunnah terhadap al-Qur"an yang ketiga tersebut yaitu ketika kaidah fikih dijadikan sebagai pertimbangan utama untuk menyelesaikan persoalan hukum yang tidak ada nassnya (fi ma la nass fihi) baik al-Qur"an maupun as-Sunnah. Qawā'id fighiyyah sebagai dalil mandiri atau otonom ini dalam metode penemuan hukum disebut dengan metode argumentasi atau metode penalaran hukum (redenering atau reasoning) yaitu metode yang digunakan untuk menetapkan hukum yang tidak ditetapkan oleh perundang- undangan. ${ }^{11}$

Dari penelusuran penulis, posisi qawaid fighiyyah sebagai dalil mandiri

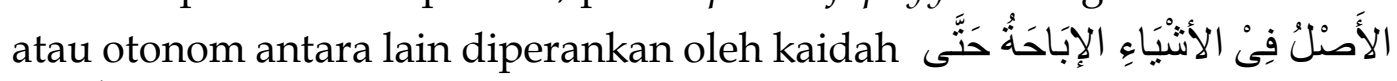
Posisi kaidah ini sebagai dalil mandiri banyak digunakan dalam fatwa bidang keuangan syari'ah. Prinsip kaidah ini adalah segala sesuatu yang tidak ada ketentuannya dalam nass (ghairu mansusah), baik ketentuan diperintah/halal atau dilarang/haram, maka hukumnya boleh. Dengan kata lain makna kemandirian kaidah tersebut adalah ketika "suatu tindakan/aktifitas" tidak ada dalil yang membolehkan atau "sesuatu (hewan, tumbuhan)" tidak ada ketentuan nass yang menghalalkan, maka kaidah tersebut dapat dijadikan dalil untuk menetapkan "boleh" atau "halal".

Prinsip yang diusung kaidah tersebut sangat penting dijadikan pedoman untuk mengantisipasi persoalan-persoalan yang berkebang di luar teks. Sebab tidak mungkin penalaran tehadap nas dapat mencakup detail-detail kasus hukum yang berkembang dinamis. Oleh karena itu -sebagaimana telah dijelaskan pada bab sebelumnya- berbagai aktifitas muamalah di bidang transaksi keuangan atau produk jasa perbankan yang tidak pernah ada pada masa Rasul atau belum ada ketentuannya

\footnotetext{
${ }^{10}$ Posisi as-Sunnah sebagai taqrir atau taqnin antara lain dicontohkan tentang ketentuan hadis yang melarang nikah dengan saudara sepersusuan dan ketentuan tentang keharaman binatang yang bertaring dan buas. Ketentuan hukum tentang dua hal tersebut tidak ada dalam al-Qur"an, tetapi ada dalam hadis riwayat Bukhariy dan Muslim.

11 Dalam hukum positif terdapat tiga metode penemuan hukum, yaitu (1) metode interpretasi, (2) metode argumentasi, dan (3) metode eksposisi (konstruksi hukum). Lihat Bambang Sutiyoso, Metode Penemuan Hukum: Upaya Mewujudkan Hukum yang Pasti dan Berkeadilan (Yogyakarta: UII Press, 2015), hlm.104-143.
} 
dalam kitab-kitab fikih, MUI menggunakan kaidah di atas sebagai dalil utama.

Kaidah lain yang berperan sebagai dalil mandiri adalah kaidah

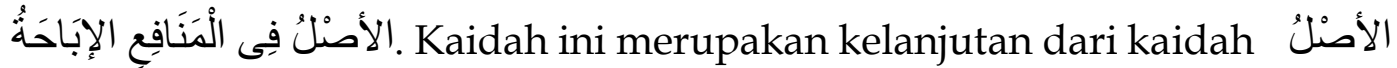

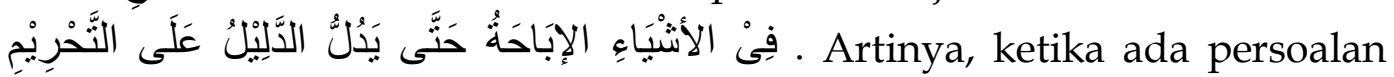
yang belum ada ketentuan hukumnya, kemudian ditetapkan boleh, maka salah satu standarnya adalah "manfaat". Penggunaan kaidah tersebut sebagai dalil mandiri atau otonom sangat dominan dalam fatwa bidang pangan, obat-obatan, dan kosmetika, yaitu fatwa-fatwa: (1) Pewarna Makanan dan Minuman dari Serangga Conchineal, ${ }^{12}$ (2) Penggunaan Shellac Sebagai Bahan Pangan, Obat dan Kosmetika,13 (3) Budi Daya Cacing dan Jangkrik, ${ }^{14}$ dan (4) Pemanfaatan Bekicot Untuk Kepentingan Non Pangan. ${ }^{15}$ Persoalan-persoalan tersebut muncul akibat perkembangan kemajuan teknologi, oleh karena itu MUI kesulitan menemukan nasnya. Maka dalam menyelesaikannya, yang dijadikan pertimbangan utama adalah prinsip "manfaat" dengan merujuk kaidah di atas.

Menurut MUI, serangga conchineal dan shellac, tidak ada ketentuan hukumnya baik dilarang atau diharamkan, maka MUI menetapkan fatwa halal untuk digunakan sebagai bahan pewarna makanan atau minuman maupun kosmetika, karena dianggap "bermanfaat" dan tidak membahayakan. ${ }^{16}$

Tentang fatwa Budi Daya Cacing, MUI menjelaskan bahwa meskipun hukum memakan cacing hukumnya diperselisihkan oleh para ulama, namun membudidayakannya untuk diambil manfaatnya, misalkan untuk pakan burung, hukumnya boleh (mubah). ${ }^{17}$ Demikian juga tentang Budi Daya Jangkrik, hukumnya boleh karena ada manfaatnya, misalnya untuk bahan obat atau kosmetika. ${ }^{18}$ Adapun tentang Pemanfaatan Bekicot Untuk Kepentingan Non Pangan, seperti untuk obat dan kosmetika luar, MUI memperbolehkannya, sepanjang bermanfaat dan tidak membahayakan. ${ }^{19}$

\footnotetext{
12 Fatwa MUI No. 27 Tahun 2013 tanggal 13 Juli 2013

13 Fatwa MUI No. 33 Fatwa 2011 tanggal 10 Agustus 2011.

14 Fatwa MUI No. Kep. 139/MUI/IV/2000 tanggal 18 April 2000

15 Fatwa MUI No.24 Tahun 2012 tanggal 31 Mei 2012.

16 Sekretariat MUI, Himpunan Fatwa MUI, hlm. 910

17 Sekretariat MUI, Himpunan Fatwa MUI, hlm. 737

18 Sekretariat MUI, Himpunan Fatwa MUI, hlm. 737

19 Sekretariat MUI, Himpunan Fatwa MUI, hlm. 937
} 
Dari uraian di atas dapat disimpulkan, terkait dengan persoalan binatang dalam konteks untuk obat dan bahan kosmetika, dasar pemikiran utama yang dijadikan untuk menetpkan fatwa adalah "kemanfaatan", dan kaidah yang digunakan sebagai dalil dalam semua persoalan di atas adalah الأصنْلُ فِى الََْنَافِعِع الإِبَاحَةُ Sedangkan dalam konteks untuk dikonsumsi (dimakan), MUI cenderung berpikir tekstual dan hatihati (ikhtiyā ), yaitu mengikuti nașs (Al-Qur"an dan as-Sunnah) atau pendapat-pendapat ulama yang ada dalam kitab-kitab fikih. Oleh karena itu diperbolehkannya cacing atau bekicot untuk kepentingan obat adalah untuk obat luar, bukan jenis obat yang dimakan atau diminum.

Prinsip manfaat sebagai dasar pertimbangan menetapkan fatwa sangat strategis untuk mengembangkan hukum Islam (fikih). Dengan menyelesaikan persoalan hukum tidak hanya melihat ada atau tidak ada nas, tetapi juga mempertimbangkan nilai manfaat, maka hukum akan bergerak dinamis, karena nilai kemanfaatan itu sendiri juga akan bergerak dengan perkembangan teknologi dan kebutuhan masyarakat. Demikian juga dengan nilai kemanfaatan dijadikan pertimbangan ketetapan hukum, maka persoalan-persoalan hukum yang tidak ada nass nya dapat diselesaikan, dan hal itu dibuktikan dengan fatwa-fatwa yang sudah ditetapkan oleh MUI di atas.

Prinsip manfaat ini juga penting bila dilihat dari konsep aksiologi hukum yaitu hukum akan efektif apabila mempunyai nilai "manfaat". ${ }^{20}$ Hukum yang baik adalah hukum yang dapat memberi "manfaat" kepada setiap subyek hukum. ${ }^{21}$ Kemanfaatan merupakan bagian dari kebahagiaan

${ }^{20}$ Dalam filsafat, aksiologi diartikan sebagai teori yang mempelajari nilai secara umum. Aksiologi juga disebut theory of value (teori nilai). Nina W. Syam, Filsafat sebagai Akar Ilmu Komunikasi, (Bandung: Simbiosa Rekatama Media, 2013), hlm. 151. Bila aksiologi ditarik ke wilayah ilmu, maka ia masuk dalam pembicaraan filsafat ilmu. Dalam filsafat ilmu, aksiologi digunakan untuk membahas nilai kegunaan ilmu. Lihat Mukhtar Latif, Orientasi ke Arah Filsafat Ilmu (Jakarta: Kencana, 2016), hlm. 230. Atau untuk mencari jawaban atas pertanyaan; untuk apa kegunaan ilmu? Lihat Biyanto, Filsafat Ilmu dan Ilmu Keislaman (Yogyakarta: Pustaka Pelajar, 2015), hlm. 164. Dalam kaitannya dengan hukum -termasuk hukum Islam atau fikih-, aksiologi merupakan bagian yang bersifat inheren dan tidak terpisahkan dalam proses penciptaan dan pembentukan sebuah hukum. Aksiologi hukum mempunyai peran untuk menentukan nilai-nilai dalam hukum, seperti kemanfaatan, kepastian, dan keadilan. Bila dikaitkan dengan qawa'id fighiyyah sebagai ilmu, maka aksiologi di sini adalah untuk menguji qawa'id fighiyyah ketika digunakan sebagai dasar penetapan hukum, dalam konteks ini adalah fatwa MUI, sejauh mana hukum yang diproduk tersebut bermanfaat.

21 Tata Wijayanta, "Asas Kepastian Hukum, Keadilan, dan Kemanfaatan dalam Kaitannya dengan Putusan Kepailitan Pengadilan Niaga", Jurnal Dinamika Hukum 14, no. 
(happiness), oleh karena itu baik buruknya suatu hukum bergantung pada apakah hukum itu memberikan kebahagiaan atau tidak pada manusia, dan salah satu bentuk kebahagiaan adalah kemanfaatan. Selain itu, validitas hukum tidak hanya ditentukan oleh hukum itu sendiri, melainkan ditentukan oleh nilai 22 dan nilai yang ada dibalik teks hukum merupakan titik tertinggi dari sebuah hukum. ${ }^{23}$ Oleh karena itu, dalam membuat hukum harus mempertimbangkan nilai, dan salah satu dari nilai hukum adalah kemanfaatan. Kaidah الأصْلُ فِى الْمَنَافِعِ الإبَاح merupakan dalil untuk memproduk hukum dalam rangka mewujudkan nilai manfaat tersebut.

Demikian juga fatwa tentang "kloning" pada hewan atau tumbuhan. Kloning pada hewan dan tumbuhan merupakan persolan hukum yang muncul akibat kemajuan IPTEK, karena itu tidak ada ketentuan hukumnya apakah dilarang atau diperbolehkan. Dalam fatwanya MUI memperbolehkan kloning pada hewan dan tumbuhan karena pertimbangan "manfaat" yaitu antara lain efisiensi reproduksi. ${ }^{24}$

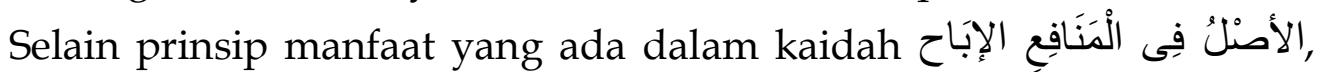

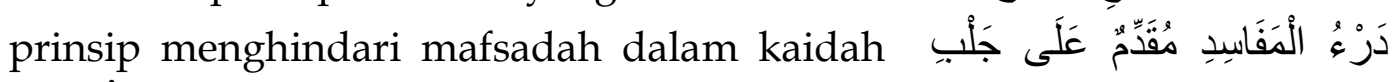
الَْصَلِحِح juga diposisikan sebagai dalil mandiri. Hal ini dapat dilihat dalam fatwa tentang kloning. ${ }^{25}$ Kloning merupakan persolan hukum yang muncul akibat kemajuan IPTEK, karena itu tidak ada ketentuan hukumnya apakah dilarang atau diperbolehkan. Kloning terhadap manusia, walaupun ada manfaatnya, ${ }^{26}$ tetapi di sisi lain juga ada mafsadahnya. Oleh karena itu menhindari mafsadah ${ }^{27}$ sesuai prinsip

2 (Mei 2014), Yogyakarta: Fakultas Hukum Universitas Gadjah Mada, hlm. 216-226.

22 Lihat dalam Hans Kelsen, General Theory of Law and State (New York: Russel and Russel, 1971), hlm. 122.

${ }^{23}$ Maria Farida Indrati, Ilmu Perundang-Undangan (Yogyakarta: Kanisius, 2007), hlm. 2022

24 Sekretariat MUI, Himpunan Fatwa MUI, hlm. 753

${ }^{25}$ Fatwa MUI No. 3/MUNAS VI/MUI/2000 tanggal 29 Juli 2000

26 Manfaat kloning tehadap manusia yang dikemukakan oleh MUI antara lain rekayasa genetik lebih efisien dan manusia tidak perlu khawatir akan kekurangan organ tubuh pengganti (jika diperlukan) yang biasa diperoleh melalui donor. Dengan kloning ia tadak akan lagi kekuranfgan ginjal, hati, jantung, darah, dan sebagainya, karena ia dapat mendapatkan dari manusia hasil teknologi kloning. Lihat Sekretariat MUI, Himpunan Fatwa MUI, hlm. 751

27 Adapun mafsadat (dampak negatif) yang ditimbulkan antara lain ketidakjelasan nasab anak hasil kloning dan institusi perkawinan yang disyariatkan oleh agama sebagai salah satu untuk melahirkan atau memproduksi generasi secara sah menjadi tidak diperlukan 


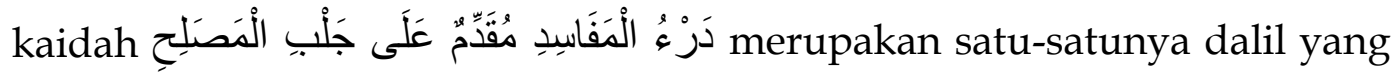
digunakan oleh MUI dalam menetapkan fatwa haram tentang Kloning terhadap manusia. Adapun kloning pada hewan dan tumbuhan MUI memperbolehkan karena pertimbangan "manfaat" yaitu antara lain efisiensi reproduksi. Oleh karena itu tentang Kloning ini ada dua fatwa hukum yang dikeluarkan oleh MUI, yaitu boleh untuk kloning hewan atau tumbuhan, dan prinsip yang digunakan adalah الأصْنُ فِى الْمَنَافِِع dan tidak boleh untuk kloning manusia dan kaidah yang digunakan

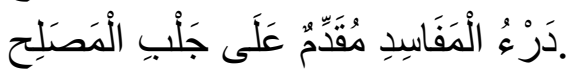

Selain prinsip manfaat dan menghindari mafsadah yang ada pada dua kaidah di atas, kaidah العَادَةُ كُحَكََّةُ dan beberapa kaidah cabangnya, juga diposisikan sebagai dalil mandiri atau otonom. Hal ini dapat dilihat dalam fatwa Metode Pengakuan Keuntungan at-Tanwil bi al-Murabahah (Pembiayaan Murabahah) di Lembaga Keuangan Syari'ah. ${ }^{28}$ Dalam keputusan fatwa tentang hal tersebut dijelaskan bahwa metode pengakuankeuntungan murabahah dan pembiayaan murabahah boleh dilakukan apabila memenuhi syarat dilakukan secara proporsional dan tidak bertentangan dengan kebiasaan/'urf/adat (العُرْف, العَادَةُ ) yang berlaku di kalangan para pedagang dan Lembaga Keuangan Syari'ah (LKS). ${ }^{29}$ Ketika MUI memperbolehkan pembiayaan murabahah di Lemabaga Keuangan Syari' ah dengan syarat harus sesuai 'urf/adat, dalil

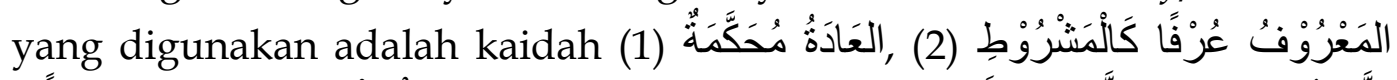

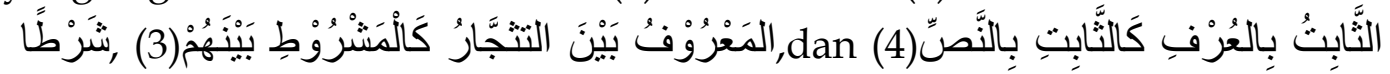
.30

Terkait adat atau 'urf sebagai dasar penetapan hukum, S. Waqar Ahmed Husaini mengemukakan, Islam sangat memperhatikan tradisi dan realitas sosial untuk dijadikan sumber hukum dengan penyempurnaan dan batasan-batasan tertentu. Prinsip demikian terus dijalankan oleh Nabi Muhłammad SAW Kebijakan-kebijakan beliau yang berkaitan dengan hukum yang tertuang dalam sunnahnya banyak mencerminkan kearifan beliau terhadap tradisi-tradisi para sahabat atau realitas sosial

lagi, karena reproduksi dapat dilakukan tanpa melakukan hubungan seksual, Himpunan Fatwa MUI, hlm. 751

${ }^{28}$ Fatwa DSN No. 84/DSN-MUI/XII/ 2012 tanggal 16 September 2000.

${ }^{29}$ Sekretariat MUI, Himpunan Fatwa Keuangan Syariah, 801-802

30 Sekretariat MUI, Himpunan Fatwa Keuangan Syariah, 793-794 
masyarakat. ${ }^{31}$ Pentingnya memperhatikan tradisi dan realitas sosial (analisis sosiologis) yang dikemukakan oleh Ahmed Husaini tersebut difasilitasi oleh kaidah induk kelima yaitu العَادَةُ مُحَكََُّْْة Kaidah fikih ini sebagai legitimasi bahwa realitas (al-waqi') yang ada di masyarakat dapat dijadikan pertimbangan dalam menyelesaikan suatu persoalan hukum. Realitas empiris yang ada di masyarakat tidak boleh diabaikan. Lebih rinci tentang bagaimana realitas masyarakat harus direspon, diuraikan dalam

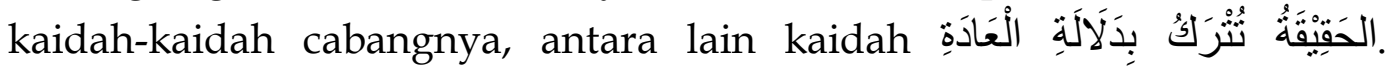
Kiadah ini memberikan arahan agar dalam memahami kata dalam sebuah teks, mempertimbangkan makna yang berlaku atau sesuai dengan adat atau urf. Makna yang dianggap sebagai makna hakikat (الحَقِيَقَةُُة) dapat dikesampingkan (تُنْرَكَ) bila bertentangan dengan adat atau 'urf. Kaidah

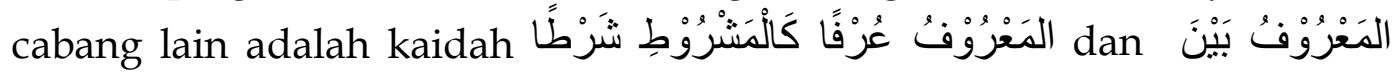

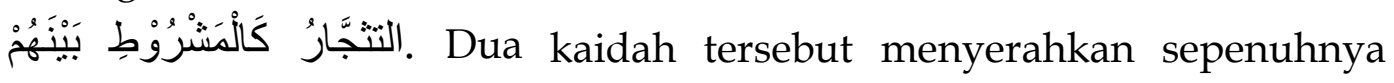
terhadap masyarakat dalam aktifitas perekonomian atau perdagangan untuk membuat model atau bentuk transaksi dan kerja sama, apabila tidak ada ketentuannya dalam nass. Ketika suatu ketentuan hukum bersifat mutlak atau tidak ada penjelasan dari syara' ataupun bahasa

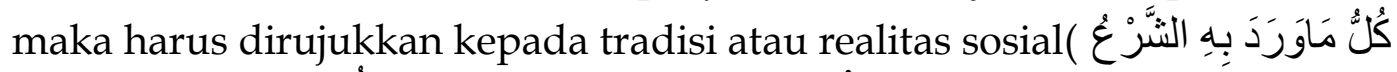

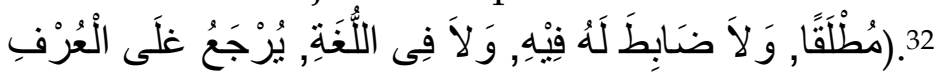

Ketentuan hukum yang didasarkan atas adat atau 'urf mempunyai

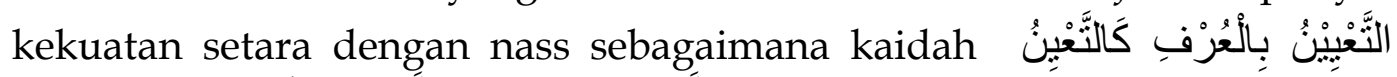

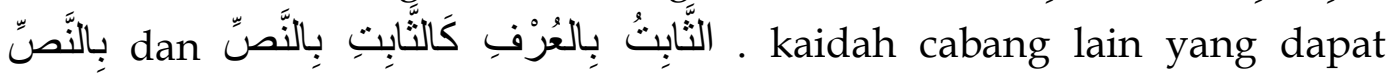

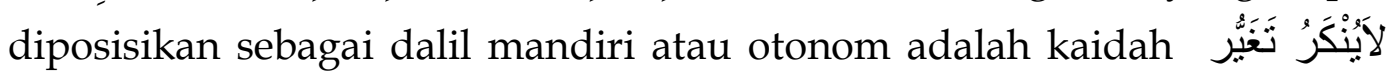

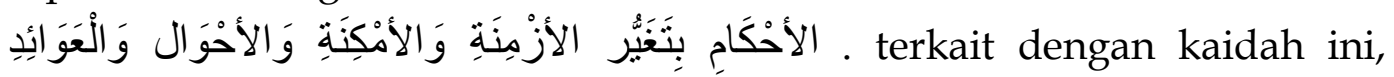
'Abdul 'Aziz Muhammad 'Azzam menjelaskan bahwa salah satu faktor yang menyebabkan hukum dapat berubah adalah realitas tradisi masyarakat. ia mengemukakan:

أن الأحكام الثرعية الإجتهادية تتغير بتتغير الأوضاع والأحوال الزمنية, فإذا كان الناس

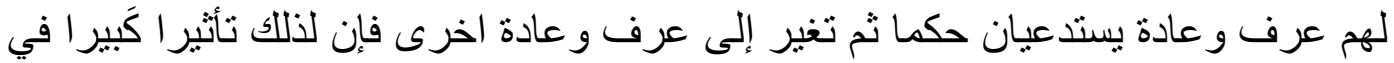

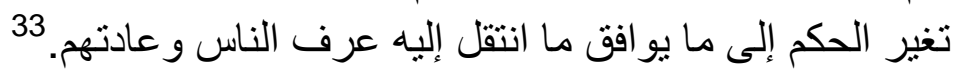

31 S.Waqar Ahmad Husaini, Sistem Pembinaan Masyarakat Islam, terj. Ahmad Mahyuddin (Bandung: Pustaka, 1983), hlm. 73-74

32 Ahmad bin Muhammad Mustafa Ahmad Az-Zarqa', Syarhu al-Qawaid al-Fighiyyah) (Beirut: Dar al- Qalam, t.t.), hlm. 136

${ }^{33}$ Abdul Aziz Muhammad Azzam, al-Qawavid al-Fiqhiyyah (Kairo: Dar al-Hadis, 2005), hlm. 
Sesungguhnya hukum-hukum syariat yang bersifat ijtihadiy dapat berubah seiring dengan perubahan keadaan dan kondisi waktu, apabila kebiasaan dan adat suatu masyarakat dijadikan dasar hukum kemudian keadaan dan adat tersebut berubah, maka perubahan itu membawa pengaruh besar dalam perubahan hukum )dari ketentuan hukum yang sudah ada) kepada hukum yang sesuai dengan kebiasaan dan adat yang baru.

Hal yang sama juga dikemukakan oleh Abu Umamah Nawwar asy-Syili. Menurutnya realitas sosial tidak hanya penting dijadikan dasar penetapan hukum, lebih dari itu realitas sosial merupakan pondasi yang dengannya hukum menjadi dinamis dan fleksibel. Karena realitas sosial (adat, 'urf) sangat mungkin mengalami perubahan dan berbeda antara satu tempat dengan tempat lain, maka ketetapan hukum yang didasarkan atas realitas sosial (adat,'urf) tentu dapat mengalami perubahan dan dapat menyesuaikan dengan realitas yang ada.34 Pernyataan tersebut menguatkan bahwa adat atau 'urf dapat dijadikan dasar pertimbangan oleh seorang mufti atau mujtahid dalam memberikan jawaban-jawaban atau menyelesaikan persoalan-persoalan hukum.

Selain kaidah di atas, posisi qawā'id fiqhiyyah sebagai dalil mandiri atau otonom juga diperankan oleh kaidah مَاحَرَمَ أَخْذُهُ حَرَمَ إعْطَاؤُه . Kaidah ini digunakan sebagai dalil fatwa tentang penyitaan aset pelaku tindak pidana korupsi dan tindak pidana pencucian uang. ${ }^{35}$ Persoalan penyitaan aset pelaku tindak pidana korupsi muncul ketika pemerintah pada tahun 2011 membuat Rancangan Undang-Undang (RUU) Perampasan Aset Tindak Pidana Korupsi. Persoalan tersebut dibahas oleh MUI karena ada sebagian masyarakat yang mempertanyakan RUU tersebut jika disyahkan sebagai UU, dalam perspektif hukum Islam. Sebagai hal baru tentu persoalan tersebut tidak ditemukan dalam nass. Dengan merujuk kaidah di atas MUI memperbolehkan RUU tersebut dijadikan UU. ${ }^{36}$ Logika penggunaan kaidah tersebut, karena harta korupsi diperoleh dengan cara haram, maka tidak boleh dipergunakan untuk apapun. Ketika harta tersebut tidak boleh dipergunakan maka negara yang harus mengambil alih (menyita) untuk kemaslahatan rakyat dan sekaligus untuk mempersempit peluang kepada koruptor menggunakan harta hasil

198

34 Abu Umamah Nawwar asy-Syiliy, al-'Aql al-Fiqhiy (Kairo: Dar as-Salam, 2008), hlm.102

35 Keputusan Ijtima" Ulama Komisi Fatwa se-Indonesia ke 4 tahun 2012 tanggal 1 Juli 2012

36 Sekretariat MUI, Himpunan Fatwa MUI, 1205-1206 
korupsi.

Demikian juga mengenai tindak pidana pencucian uang, sama dengan penyitaan aset pelaku tindak pidana korupsi. Persoalan ini menjadi pembahasan MUI untuk merespons pertanyaan di kalangan masyarakat tentang bagaimana dalam perspektif hukum Islam terkait UU No. 15 Tahun 2003 tentang Tindak Pidana Pencucian Uang. MUI berpendapat bahwa kebijakan pemerintah membuat Undang-Undang Tindak Pidana Pencucian Uang tidak bertentangan dengan hukum Islam. Berdasarkan kaidah tersebut dalam fatwanya MUI menjelaskan: 1) Pencucian uang merupakan tindak pidana karena merupakan penggelapan dengan tujuan menyembunyikan dan menyamarkan aset yang diperoleh secara tidak sah

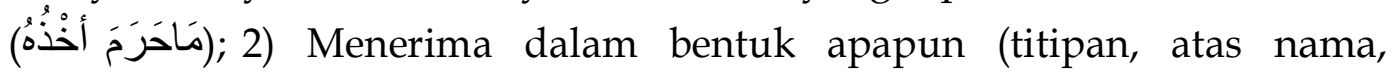
dan yang sejenisnya) dan memanfaatkan uang atau aset yang berasal dari korupsi hukumnya haram (حَرَمَ إعْطَاؤُه). ${ }^{37}$ Dengan alasan tersebut tersebut MUI memfatwakan bahwa UU No. 15 Tahun 2003 tentang Tindak Pidana Pencucian Uang tidak bertentangan dengan hukum Islam.

\section{Penutup}

Penggunaan qawàid fiqhiyyah sebagai dalil ('adillah al-ahkam) dalam fatwa-fatwa MUI, diposisikan sama sebagimana posisi as-Sunnah terhadap al-Qur'an yaitu sebagai ta'kid/mu'akkid,tabyin/mubayyin, dan taqrir/taqnin. Posisi qawaild fiqhiyyah sebagai $t a^{\prime} k i d / m u^{\prime} a k k i d$ digunakan apabila persoalan hukum yang dibahas oleh MUI sudah ada nasksnya secara tekstual dan qat'iy, kemudian MUI mencantumkan kaidah fikih yang substansinya sama dengan nass yang digunakan sebagai dalil untuk menyelesaikan persoalan tersebut. Posisi qawaild fiqhiyyah sebagai

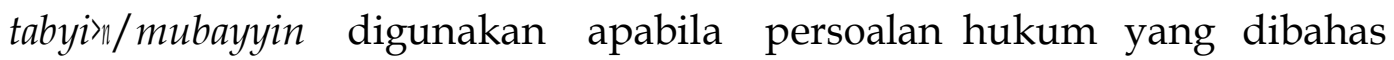
oleh MUI, nass yang dicantumkan bersifat umum. Adapaun posisi qawaiid fiqhiyyah sebagai taqrir/taqnin digunakan sebagai dalil apabila persoalan yang dibahas tidak ditemukan nas)snya secara tekstual dan qat' iy. Dalam kondisi demikian MUI menggunakan qawaid fiqhiyyah (prinsip-prinsip yang ada dalam kaidah-kaidah fikih) sebagai pertimbangan utama (dalil mandiri) untuk menyelesaikan persoalan tersebut.

\section{Daftar Pustaka}

Abdul Aziz Muhammad Azam. Qawai'd al-Fiqh al-Islami. Mesir: Ar-Risalad

37 Sekretariat MUI, Himpunan Fatwa MUI, 1211-1212 
ad- Dawliyyah, 1999.

Abdul Wahhab Khallaf. Ilmu Usul al-Figh. Kairo: Maktabah Islamiyyah, 1990.

Abu Umamah Nawwar Asy-Syili. al-'A ql al-Fiqhi. Kairo: Dar as-Salam, 2008.

Ahmad bin Muhammad Mustafa Ahmad az-Zarqa. Syarhu al-Qawaid alFighiyyah. Beirut: Dar al-Qalam, 1989.

Amir Syarifuddin. Ushul Figh I. Jakarta: Kencana, 2008.

Asrorun Ni'am Sholeh. Metodologi Penetapan Fatwa Majelis Ulama Indonesia; Penggunaan Prinsip Pencegahan dalam Islam. Jakarta: Erlangga, 2016.

As-Suyuti Jalaluddin Abdurrahman ibn Abi Bakr. al-Asybah wa an-Nazir. Beirut: Dar al- Fikr, t.t.

Bambang Sutiyoso. Metode Penemuan Hukum: Upaya Mewujudkan Hukum yang pasti dan Berkeadilan. Yogyakarta: UII Press, 2015.

Biyanto. Filsafat Ilmu dan Ilmu Keislaman. Yogyakarta: Pustaka Pelajar, 2015.

Muhammad Sidqi ibn Ahmad ibn Muhammad Al-Burni. al-Waji fi INllah alQawàid al- Fiqhiyyah al-K\{ulliyah. Beirut: Mu'assasat ar-Risa>lah, 1996.Indrati, Maria Farida. Ilmu Perundang-Undangan. Yogyakarta: Kanisius, 2007.

Forum Kajian Ilmiah PP Lirboyo. Kilas Balik Teoritis Fiqh Islam. Kediri: Pokja Forum Karya Ilmiah, 2005.

Hans Kelsen. General Theory of Law and State. New York: Russel and Russel, 1971.

Mukhtar Latif. Orientasi ke Arah Filsafat Ilmu. Jakarta: Kencana, 2016.

Mohammad Atho Mudzhar. Fatwas of The Council of Indonesia Ulama: A Study of Islamic Legal Thought in Indonesia 1975-1988. Jakarta: INIS, 1993.

Nina W. Syam. Filsafat sebagai Akar Ilmu Komunikasi. Bandung: Simbiosa Rekatama Media, 2013.

S. Waqar Ahmad Husaini. Sistem Pembinaan Masyarakat Islam. Terj. Anas Mahyuddin. Bandung: Pustaka, 1983.

Syafiq Hasyim. Council of Indonesian Ulama (Majelis Ulama Indonesia, MUI) and its Role in the Shariatisation. Berlin: Freie Universitat Berlin, 2013.

Sekretariat MUI. Himpunan Fatwa Keuangan Syariah Dewan Syariah Nasional (DSN) MUI. Jakarta: Erlangga, 2014.

Sekretariat MUI. Pedoman Penyelenggaraan Organisasi MUI. Jakarta: MUI Pusat, 2001. Sekretariat MUI. Himpunan Fatwa MUI Sejak 1975. Jakarta: 
The Indonesian Journal of Islamic Law and Civil Law

Vol. 2, No. I, April, 2021, ISSN. xxx - xxx

Erlangga, 2015.

Wijayanta, Tata. "Asas Kepastian Hukum, Keadilan, dan Kemanfaatan

Dalam Kaitannya dengan Putusan Kepailitan Pengadilan Niaga", Jurnal Dinamika Hukum 14, no. 2 (Mei 2014), Yogyakarta: Fakultas Hukum Universitas Gadjah Mada, 216-226. 